\title{
Celebrity 'Ulama': Contiguity Religion and Popular Culture
}

\author{
Intan Kumalasari ${ }^{1}$, Darliana Sormin ${ }^{2}$, Muhammad Irsan Barus ${ }^{3}$ \\ ${ }^{1}$ Lecturer in IAIDU Asahan, Indonesia \\ ${ }^{2}$ Lecturer in UMTS Padangsidimpuan, Indonesia \\ ${ }^{3}$ Lecturer in STAIN Mandailing Natal, Indonesia \\ Email: intankumalasari866@gmail.com
}

\begin{abstract}
:
Post-1998 is the spread of spiritualism discourse. The emergence of celebrity 'ulama' in Islamic expression of contemporary Indonesian treasury is one example of how popular culture with a set of ideologies taking advantage of the rise of Islam. Television became an agent of a culture to the people with his ability as a link between one culture with another culture. Televisions have unpacked the real with the imaginary. With television all things can be esthetizatied, the sacred and the profane into somersaults. Television media such strength finally gave birth to a new religious authority, called celebrities 'ulama'. Factors caused by the emergence of celebrity "ulama' are sociological, which characterized by many people who prefer to watch the celebrity 'ulama' than watching Conventional Ulama. Then supported by sophisticated Tecnology Science, the stage, and commodification. This shows that Islam has been negotiating with the market and subsequently published widely in the public sphere as a form of freedom of expression in the new order in which the strength of the potential of Islam to be appreciated by the government. This can be described as a form of commodification of religion in the sense of religious values commercialized for profit.

Keyword:

Ulama; celebrities; culture; commodification.
\end{abstract}

\section{Introduction}

Ulama have status of a very urgent and strategic position in Islam. They even described as the inheritors of the prophets. Those who are called will direct and lead the people. They also lanterns life. As contained in the hadith:

و إن العلماء ورثثة الأنبياء وإن الأنبياء لم يورثو ا دينار ا و لا درهما ورثوا العلم فمن أخذه أخذ بحظ و افر "And indeed the Ulama are the inheritors of the prophets. And indeed the Prophets do not inherit the dinar and dirham and they just pass on knowledge, then anyone who took it means he has taken a perfect portion" (HR. Imam Turmuzi and Ibn Majah).

In the Indonesian context, Ulama also have different designations such areas such as kiai (Java), Ajengan (Sunda), Tengku (Aceh), Sheikh (North Sumatera/Tapanuli) and Tuan Guru (Nusa Tenggara and Kalimantan).

In general terms Ulama refers to certain qualifications of the followers of the Prophet Muhammad. This term did not refer to any particular social class or group as the other terms in Alquran, for example Muttaqin (the cautious) or Abli Ibadah (devout). As far as is referred to in Alquran, ulama (plural of Alim) is the predicate that refers to the person's scientific qualifications. Although there are signs that show their submission to Allah as other properties owned by someone Alim, but the term itself is more dominant show the scientific side someone. 
Dawam Raharjo gives an indication that the Ulama have the following characteristics: 1) as the carrier of religious traditions, 2) a person who is legally understand Islam, and 3) as law enforcement Jurisprudence.

Indonesian society in Islamic sociology, ulama also called Kiai referring to "mastery of the treasures of the yellow book, the leader of pesantren," or a Muslim who dominate the fields of monotheism, fiqh and Sufi as well as an expert. ". It basically functions played by ulama or Kyai was as a teacher of Alquran, a teacher of classical Islamic books, teacher institutes, teachers of science lessons (witchcraft), as well as preachers. In a rural environment, a Kyai even more than just a religious figure, he is also the place to ask about all the problems of life experienced by the community, such as matchmaking, healing, and so forth.

In history, Ulama became an ideal term in which the expected load the entire quality of both existing goodness on the jurists', Reporters, and Sufis. ulama is expected to master the science of law, traditions and also have spiritual qualities as a Sufi.

Nowadays, Ulama in touch with modernity. The most phenomenal contiguity is contiguity ulama with mass media and electronics. This gave rise to celebrity 'ulama', the ulama who entertain in spreading religious. This paper will discuss celebrities 'ulama' and models contribution activities.

\section{Discussion}

\subsection{Socio-Religious Background Celebrity 'Ulama'Phenomenon}

The invention of printing technology in the 15th century that flourished in the following centuries to shift the transmission process of scientific and religious authorities who gave birth to a base group of Ulama in the era of manuscripts. Printing technology that is capable of printing various paper in large quantities shift transmission and a base style religious authority in Islamic societies. Printing jeopardize what is called "person-to-person transmission of knowledge" and the authoritative transmission of various concepts related to the style. The impact is more recent emergence of religious authority who challenge the authority of religious Ulama.

This can be seen for example on activity of Ulama studying archipelago secaraface to face with the teachers so that the teachers are very well acquainted personally with each student and therefore know the talents and needs of strive to meet these unique needs.

Printing era gave birth to a new religious elite, namely the Muslim Ulama. Era that is where everyone can get access to read a book and science Islam without studied intensively to a scholar. At that time, access to classical texts more easily which makes ulama authority as a translator of classical works received little disclaimer. Ulama who has the authority to distribute the understanding of the classics, and then to a religious understanding of the people slowly began to fade.

On the other hand, the increasing religious consumption can be seen as a result of modernization, urbanization and globalization. Since 1970, Indonesia has been through socioeconomic changes that dramatically. Soeharto regime opened the country to foreign funds in large quantities which emphasizes the development of the industrial sector, and financial resources. With the national growth rate throughout the 1970s and 1980s more than $7 \%$ annually makes big cities in Indonesia to be the center of the economic boom. More and more people from the village moved to the big cities such as Jakarta, Surabaya, Bandung, Medan and Makassar to seek educational opportunities and better jobs. 
This situation makes a lot of advantages and a wealth of material that is mixed with the pressures of professional life which is full of competition, dense urban settlements, and the interplay between diverse cultures. Religious behavior is one field that has undergone dramatic changes in the cities as a result of globalization and modernization.

Many people are initially looking for teachers to study religious issues that help them carry out religious rites in accordance with the written texts of the classical texts. But that changed after the arrival of the 21st century as the third millennium that began in 2000 (the millennium of television). Television waves penetrate the walls of the room everyone.

Moral certainties and assumptions which underlie life comfortable that have moral certainty that often comes from the village eroded by modern urban culture. The erosion of running a massive transfer sparkling city of culture through television channels.

Television is one of the important media in modern society to represent itself as a major public space that determines the dynamics of the social, political, and cultural. Television is also a major source of the public to information will the surrounding world. This led to television as a medium that has contributed to the community in defining reality. Television can define a person's life in accordance with what is considered to be supportive of commodity capitalism news media. Television has become the face of a new tyranny, which is not only real but reality have constructed a new reality beyond the real or pseudo-reality.

A state of shock identity displayed by the media made a lot of people and then look for the sources of moral guidance and assistance through religion. Sometimes this quest follows the line of the religious market follow his personal tastes to find a new identity because of the ease of access to information provided by the media. The "religious seeker" is more eclectic look for the moral guidance from fundamentalism to metaphysical beliefs. They seek religious variations that suits their tastes and needs.

Plus more in line by develop globalized information technology, then everyone can talk as though Ulama have undermined the divider walls and make it as liberation partition information. This situation has brought Indonesia's Muslim population into two typologies of ulama, called by celebrities'ulama' and, traditional ulama.

Television has become an integral part of modern life, the force of "hypnotic" to enjoy it. Television has become a necessity that must be met, even by all circles. Broadcast television with a wide range of event into daily menus in waiting. Not infrequently television has become a better teacher in hearing than parental advice.

Television became an agent of a culture to the people with its ability as a link between one culture with another culture. Televisions have unpacked the real with the imaginary. With television all things can be esthetizatied, the sacred and the profane into somersaults. Television media such strength finally gave birth to a new religious authority, called celebrities 'ulama'.

The presence of new religious authority Television's production challenges the authority of the old religious and race to talk about Islam in the public sphere. Ulama originally specified by the command of the classical Islamic sciences is now gone with their preachers-preachers are young, fresh and completely new in the production and reproduction by television media. No more boundaries between reality and imagination Ulama in television production. 


\subsection{Forms of the Main Event Celebrities 'Ulama'}

Is a famous celebrity or famous person (usually about the artist). When an ulama has become a celebrity, then life is not much different from other celebrities. Celebrities 'ulama' would form a self-image that will give the impression you want in the form of the mass media. The best self-image of a celebrity 'ulama' displayed, then the chance to get a good impression in the mass media will also be achieved.

Good impression is what sold by celebrities 'ulama' to maintain its existence. Before dealing with the reporter for an interview, they will do some preparation, among them appear neatly and make-up, cool down in order to condition stable emotions, and discuss with management to display a positive self-image in the presence of reporters. They fully understand their meaning for their popularity.

Activities undertaken by Ulama like entertainer dressed celebrities. They are involved in the sale of Islamic products that have adjusted to the proficient-made products to meet the users needing. Many products and services emphasizing personal comfort, thenaccess and immediacy. They are also aimed at tackling the problems and anxieties of modern life.

SMS 'Kun Fayakuun' service of Yusuf Mansur provides a good example of this. Kun Fayakun Service a purpose of "easy way to pay the debt" and "easy way to get the best couple". Uje launched a service called SMS promising 'Obat Hati' users who are anxious not counseling, but also prayers and readings be comfortable. On the other hand, Aa Gym has made 'Manajemen Qalbu' as a central theme in speeches and business activities, Arifin Ilham offers romantic sms services and advices love by Islam to his customers.

The television media has managed to create the popularity of the Ulama such as Aa Gym, Yusuf Mansur, Arifin Ilham, Muhammad Nur Maulana Mahmud Salih, Dedeh Rosyidah Syarifuddin, Ummi Qurrata Ayyunin, ZackyMirza, Vitello, Abu Bakr Al-Ethiopia. Besides appearing artists who change and become Ulama, They changed course to attract public sympathy to keep their attention on the world of entertainment that is increasingly complex and challenging. In fact, sometimes exposing the private lives by selling "conversion" and "change" so that their words could be heard. Their first note on stage because of their appearance, they are now more attention because of what they say. Among the figures of the artist became ulama is Oki Setiana Dewi, Akrie Patrio, Harry Moekty, Irvan Rotor, Astri Ivo, Dian Pipik Irawati, Peggy Melati Sukma, Sakti SO7, Gito Rollies and others.

Later, as a young ulama and his wife HananAttaki, Hanien Akira and Natta Reza became quickly famous for actively delivering lectures via Instagram. They can be called as a selegram ulama, namely ulama displaying religious atmosphere with pop culture expression via instagram media. They became Muslim youths interested in his talk in the video-posting short video full of colorful images as part of the technological sophistication of the new media. With the new media technology, he or she can become a celebrity ulama who gained the full attention of the public, has many followers, so that strengthened religious authority. In fact, although in general they are not having a strong basic Islamic education that is equivalent to Ulama and not more than entertain preacher.

On the other hand there is also a well-known conventional Ulama be an actress. Their popularity is well-known by social media by his followers. There are at least 3 people who become so phenomenal, those areAdiHidayat, Khalid Basalamah and Abdul Somad, which has many followers. In addition to actively speak, Adi Hidayat and Abdul Somad also producing religious 
literature. Since 2010 to 2015, AdiHidayah has written approximately 11 books, among them: (1) The meaning of Paragraph Fasting; (2) Note Prosecutor Science; (3) At-Taisir Mushaf (only Juz 29); (4) Practical Guidelines Hadith Sciences; (5) Practical Guidelines Eid; (6) Questioning Popular Traditions. While Abdul Somad, who taught at several universities in Riau, also has written more than seven books, namely: (1)Ustadz Abdul Somad Answering, (2) Ustadz Abdul Somad About Women, (3) Practice of the Most Beloved of God. (4) 37 Popular Problems Popular, (5) 99 Questions \& Answers Regarding Shalat, (6) School of brotherhood and (7) Dakwah Road Muslim brotherhood.

These Ulama are very familiar with social media and television to spread his message. Their popularity is exposed to the public spaces are sometimes questioning his personal life and sometimes also happens to be imaged by the media which became public information that is consumed.

\subsection{Differences of Celebrity 'Ulama' and Conventional 'Ulama'}

Ulama said in the Quran at least twice, namely in surah Fatir verse 28 and Surah al-'Ankabut paragraph 197. Ulama in Quranic perspective boils down to one characteristic, namely al-Khasyyah (fear of Allah), the higher the fear of a man to his Lord, the higher the quality ulama philosophically.

ومن الناس و الدو اب و الأنعام مختلف ألو انه كذللك إنما يخثى الله من عباده العلماء إن الله عزيز غفور "And thus (also) among humans, animals, insects, and animals and livestock are of different colors (and types). Indeed, the fear of God among His servants, just Ulama. Surely Allah is Mighty, the Forgiving."

(QS. Fathir, 35: 28)

Indonesian Dictionary, said Ulama interpreted as a person versed in the knowledge of Islam. Nadirsyah Hosen added that cleric is the term to refer to Islamic religious Ulama in general. It can be understood that the Ulama are those who have expertise in the field of Islamic religious sciences such as tafsir, hadith, kalam, Arabic, like balaghah, sharf, nahwu, and so on.

This is a simple understanding of the conventional Ulama, a group of clerics learned in understanding the formulas of classical Islamic law, has a deep knowledge of tafsir and hadith. Ulama authority conventional base power is his ability to master the Islamic sciences whose truth is considered garanted up to the Prophet Muhammad through his mastery of the problems that was written in the sacred book of Muslims. In order to demonstrate the competence, authority and authenticity of a true understanding of Islam, and show continuity with the conventional Ulama, many of the non-Arab classical Ulama who write on religious matters in Arabic.

Recognition of qualifications and religious authorities a conventional Ulama refer to the basis of religious authority manuscripts period. Authorities Ulama in this period were based on rote learning and scientific abilities which are connected through the process of teacher-student transmission from generation to generation. Authorities someone evidenced by the commencement of the teachers who taught him. This system can be viewed as a model inauguration someone to fit into a social group who are named as Ulama.

Differences celebrity 'ulama' with conventional Ulama can be seen from several aspects.

First, In terms of popularity, conventional ulama lost much of Ulama celebrities. The celebrities 'ulama' using the medium of television and social media to reach the most congregants and it is still less once used by conventional Ulama. Conventional ulama prefers to deliver his talk 
away from the frenetic social media space. While celebrities 'ulama' even closer to the artists or television station to gain access to expose himself.

Second, The ability of conventional Ulama at master authority on religious matters derived from classical texts shown on the mastery of the Quran, fiqh and hadith. While celebrities 'ulama' are not so concerned with the control of the authorities and even some not from among students who are familiar with the books of yellow as a common source of religious knowledge as Aa Gym, Yusuf Mansur, Maulana and others.

Third, The contents of lectures delivered by celebrities 'ulama' focus on personal piety and religion out of politics. The staff at the television station part program also avoids the Ulama who have a strong political message.

Fourth, The conventional Ulama would normally avoid exposure to private and family life to public spaces for general public consumption. Different with celebrity 'ulama' sometimes exposes his home life to become the spotlight maintain popularity of him to remain a public debate, such as polygamy Aa Gym, Arifin Ilham, and or the way they dress and the home state of ulama.

Fifth, There is a tendency for celebrity Ulama also to sell products business through gained popularity. In addition to those "selling" spiritual values, they also sell a variety of products piety in them as Aa Gym that create multi-level marketing business, Yusuf Mansur business 'Pay Trends' and Arifin Ilham pay the bottled water business with brand 'Azzikra'.

\subsection{Celebrity 'Ulama' and Religious Culture Formation}

One of the effects of influx of celebritiesulamais the commodification of Islam. By simple modification of Islam means the commercialization Islam. Islam and its symbols into a commodity bought and sold for profit. Indeed, many who criticize the concept of commoditization when it is used in religion. The main objection is this concept ignores the spiritual motives that lie behind the phenomenon.

As the character of modern urban public life, this search using market channels. If the previous generation seeks a religion through pathways traditionally authoritative, then the new generation is valid as a client. One of the things that characterize the new generation of this city is that it is instant because of his work as modern humans. In the process of buying and selling spiritual buyers do not have communal loyalty because its axis is the "self-consuming". He is free to choose the many existing bids. He was free to buy as free as he was to go and look for new items. This can be seen in the phenomenon of Aa Gym.

Many people think that the phenomenon of propaganda by the Ulama on television is the kind of propaganda that is garish and trite. However, these protests, from a certain perspective can be seen as part of a competition among authorities. The presence of new religious authority in television production means a challenge to the old religious authority.

The emergence of celebrity Ulama also encourages Muslims to be more tends to consume certain products laden with attributes of Islam. Most Muslims buy these products because of religious commitment. Commitment is what makes many Muslim businessmen associate their service products with attributes such Syari'ah Islamic Banking, Home eating paste the Halal certificate, Syari'ah-based hotel and others. 
Celebrities 'ulama' fenomenon are also in tandem with the emergence of film and soap opera Islamic drama, books lightweight tips become good Muslims, Islamic novels, fashion magazines Muslim women, bank labeled Syariah, content ringtone that followed from the recitations of the Quran. Do intertwined still need further research. But there is no doubt due to their portrayal of Islam with a massive campaign in public spaces as a form of freedom of expression easily accepted by society.

On the other hand there is the simplification of religious messages as they sell to create the broadest possible appeal to attract customers. Market dynamics dictate that true religion was brought into popular culture. The message must be delivered in a form of entertaining and easy to digest. It is no wonder people prefer to religious message delivered by devices such dramatic lighting affects the mind, music, stage design, colorful video and techniques playful percentage that can move the emotions of the audience.

\subsection{Contributions of Socio-Religious Celebrities 'Ulama'}

Urban middle class society expects of Islam who could answer his concerns in modern city life fast-paced, busy, and full of uncertainty. They do not want Islam conservative who does not meet the modern human rationality, but they also did not quite have time for too deep and long into the Islamic scholarly discourse too serious. Besides, Islam they need is Islam reassuring private lives with services that can be accessed quickly, anywhere and anytime. Islamic character of the urban middle class needs it clearly cannot be met by traditional religious authority.

This kind of Islam needing match with the Islamic market packed in attractive packages contain individual guidance spirituality in modern life wading through rational and full of uncertainty in which the packet can be accessed anytime and anywhere personally. This requirement was captured by the capitalist system market by providing spiritual service packages are able to fulfill it. The producers are aware that these products are sold to consumers, and not coerced. As in buying and selling, the producers producing packages Islamic purchase fresh and exciting. Religious consumption in thisvolatile era. Consumers are quickly bored and looking for new trends. The maker of products to the market throws a religious package that meets the demands of the situation is shifting tastes.

Critical voice of authority increasingly showing that television can create religious authority outside the control of traditional religious authority. Celebrities 'ulama' have become a new institution. They can attend and greet the public with direct religious exhortations in the room from morning till night, even early morning. They are present in the packaging television or in the news infotainment show lined up with other artists. Even marriage, divorce, pregnancy of his wife, anniversary, medication, to leave Umroh was presented as part of a religious message celebrities 'ulama'.

On the other hand with the commodification of spiritual values by celebrities 'ulama' make Islamic expression through popular culture is becoming more common and accepted as a public discourse without much debate. Spiritually, beyond the implementation of norms and worship of Islam has spread and consumable products to be part of Islam into public life. The patterns of religious life become visible, including the tendency of Islamic learning and consumption towards more personal. All it also led to increased demand for services that require faster religious guidance, accessible and appropriate lifestyle.

Celebrities 'Ulama' also promote active devotional sufism through new styles speak on television. The program is the most famous of his 'Manajemen Qalbu' by Aa Gym and 'Zikir' program by Arifin Ilham. The members of the assembly not only committed to return to the right 
path, but they also follow a specific program that is designed and arranged so as to realize the objectives of the spiritual.

Celebrities 'Ulama' enter the practices associated with Sufism in the media in different ways. Some use spiritual experiences todramatized for public consumption. Some are using the pronunciations of remembrance which refers to the practice of the Sufism to be practiced by the congregation in daily life.

\section{Conclusion}

Television became an agent of a culture to the people with his ability as a link between one culture with another culture. Televisions have unpacked the real with the imaginary. With television all things can be esthetizatied, the sacred and the profane into somersaults. Television media such strength finally gave birth to a new religious authority, called as celebrities 'ulama'.

The emergence of the treasures of expression Celebrity 'Ulama' in Indonesia is one example of popular culture with a set of ideology carries. This shows that Islam has been negotiating with the market and subsequently published widely in the public sphere as a form of freedom of expression in the new order in which the strength of the potential of Islam to be appreciated by the government. This can be described as a form of commodification of religion in the sense of religious values commercialized for profit.

\section{References}

Azra, Azyumardi. UlamaNetwork: Middle East and Archipelago XVII and XVIII Century. Jakarta; Prenada Media 2004.

Bakar, Abu, et. al. Most Salih scramble; Shifting Identities cleric in the Millennial Era. contextuality; Religious Social Research Journal. Volume. 34. No. 2, 2017.

Burhanuddin, Jajat \& Ahmad Baedowi (ed). UlamaAnd Political Formation Of The People: Historical Overview The Indonesian Experience. Jakarta: Gramedia 2003.

Dawud Muhammad. Impressions Da'wah and the Birth of Celebrity Dai. Journal al-'is. Volume 18. Number 2, 2015.

Dhofier, Zamakhsyari. Pesantren Tradition: Studies Worldview Kyai. Jakarta: LP3ES, 1982.

Greg Fealy and Sally White. Ustadz. Celebrities, Moral \& Fatwa Business Online, Variety Islam Indonesia Contemporary Expression. Translation Ahmad Muhajir. Jakarta: Bamboo Community, 2012.

Hosen, Nadirsyah. Online Fatwa in Indonesia: From Fatwa shoping to Googling A Kyai "in Greg Fealy and Sally White (ed.), Expressing Islam: Religious Life and Politics in Indonesia. Singapore: ISEAS 2008. Indonesian Dictionary Online.

Rahardjo, Dawam M. Ensiklopedi Quran. Jakarta: Paramadina, 1996. Intellectual Intelligence and Political Behavior Nation: Minutes of Muslim Ulama. Bandung: Mizan, 1993.

Rozak, Abdul. Remote Village Community Behavioral Watching Television Footage. Aplikasia: Journal of Religion Sciences Applications. Volume 16. Number 2, 2016.

Saefulloh, Aris. Dakwabtainment: Commodification Industry Media Behind Paragraph God (KOMUNIKA Journal of Da'wa and Communication, Volume. 3 No. 2, 2009.

Muhtarom. Reproduction Ulama in the Era of Globalization. Yogyakarta: Student Library 2005

Pattipeilohy, Meilany Esther. Self-image and popularity of Artists. Preaching and Communication. Journal STAIN Curup. Volume 1. No. 2, 2016.

Wahidin, Ade. The concept of Ulama According to the Quran (Analytical Study on Surah Fatir verse 28). AlTadabbur: Journal of the Qur'an and Tafseer.

Qasim Zaman, Muhammad. The Ulama in Contemporary Islam: Custodians of Change. Princeton and Oxford: Princeton University Press, 2002. 